\title{
Anatomical Studies on Several Species of Heliotropium L. in Iran
}

\author{
Maryam ABBASI ${ }^{1}$, Farideh ATTAR ${ }^{2}$, Farrokh GHAHREMANI NEJAD ${ }^{3}$ \\ ${ }^{1}$ Islamic Azad University, Central Tehran Branch, Department of Biology, Tehran, Iran; Mar.abasi@iauctb.ac.ir \\ ${ }^{2}$ Central Herbarium of Tehran University, Department of Plant Science, School of Biology, College of Science, Tehran University, Tehran, Iran \\ ${ }^{3}$ Tarbiat Moallem University, Departments of Biology, Tehran, Iran
}

\begin{abstract}
Heliotropium spp. is distributed worldwide mainly in tropical and subtropical regions, with dry and warm temperate to semi-arid regions so that Southwest and center of Asia have considered as the main centre of origin and diversity of Heliotropium genus. Iran, with 32 species and 14 (sub) endemic species, has the highest diversity in the world followed by Pakistan and Turkey with 15 species and only one endemic species and the Arabian Peninsula with 15 species and three endemic species are in the next ranks. In order to anatomical studies on Heliotropium, twelve species of this genus were selected from different regions of Iran. The selected species included: $H$. bacciferum Forssk, H. ramossisimum BGE., H. brevilimb Boiss., H. transoxanum BGE., H. dasycarpum Ledeb, H. dyginum Forssk, $H$. aucheri Dc., H. carmanicum BGE. As perennial group and H. ellipticum Ledeb., H. lasiocarpum Fisch., H. suaveolens M.B. as annual group. In order to add more data to leaf anatomy characters, evaluating of systematic relevance and/or adaptive value of the morphological and anatomical diversity we have studied 24 anatomical characters in theses 12 species. For example shape and vascular bundles of main midrib, type of parenchyma cells located under lower epidermis of midrib, distance between vascular bundles and lower or upper epidermis, angle of between two parts of blade, number of cellular layers in lower or upper mesophylla, length of upper and lower mesophylla, type of cell wall in lower and upper mesophylla and thickness of lamina were investigated in this study. In order to this present obtained $H$. aucheri can be separated from $H$. carmanicum in $H$. aucheri subsp. carmanicum. It can be conclude that two species $H$. aucheri and $H$. carmanicum are independent species and can accept $H$. transoxanum as a sub group of $H$. dasycarpum.
\end{abstract}

Keywords: anatomy, Boraginaceae, Heliotropium, Iran, taxonomy

\section{Introduction}

Heliotropium is the second large genus in the borage family (Boraginaceae) in Iran. There are 70 species in this genus, which are commonly known as heliotropes (Akhani and Förther, 1994; Akhani, 2007). This cosmopolitan genus, with more than 300 species is found in all continents (Diane et al., 2002). The area covered by Flora Iranica, which includes the whole of Iran, Afghanistan, and some surrounding highlands in Turkmenistan, Azerbaijan, Iraq, and Pakistan, harbors the majority of the Euro-Asiatic species. However, the first taxonomic revision of this genus in Flora Iranica, accounting for 74 Heliotropium species, was exaggerated. Based on a recent revision of this genus in the area covered by Flora Iranica (Akhani and Förther, 1994; Akhani, 2007), the total number of all Southwest Asian species (the area covered by Flora Iranica and the floras of Turkey, the Arabian Peninsula, Iraq, and Pakistan) is around 70 (Akhani, 2007), still a remarkable number, comparable with the diversity of the genus in Australia with 78 species (Craven, 1996).

Heliotropium includes suffruticose perennial and annual herbs (Riedl, 1978). They are easily recognized by their partial inflorescences of scorpioid cymes and by the morphology of the highly modified stigmatic head in the flower.

The life form of all species is either an annual or lowgrowing hemicryptophyte or a small subshrub (H. baccifer$u m$ ). Many species, which grow in sandy dunes, produce long rhizomes adapted to such habitats (H. digynum). The distribution of the annual and perennial species is different (Akhani, 2007). The annual species grow in mountain and low-mountain areas, whereas the perennial species frequent desert and very dry habitats. The perennial life form is more adapted to dry zones in Heliotropium. By contrast with many therophytic species in desert areas, which bloom early in the year when there is enough moisture, Heliotropium species usually flower during the hot and warm months of the year (Akhani, 2007). In aspect of physiology Heliotropium is one of the genera in which both $\mathrm{C}_{3}$ and $\mathrm{C}_{4}$ photosynthetic pathways have been reported (Kellogg, 1999; Ziegler et al., 1981).

There are four major diversity centers of Heliotropium located in four floristic kingdoms, including the Holoarctic (Center and Southwest of Asia), Neotropic (Center and South America), Ethiopian (East and South Africa and southern Arabian Peninsula), and Australian (Craven, 1996; Diane et al., 2002; Förther, 1998; Johnston, 1928). 
36

It is worth mentioning that there are 61 Heliotropium species known in Southwest Asia (excluding Yemen). Iran, with 32 species and 14 (sub) endemic species, has the highest diversity (Akhani, 2007).

In general there is little information about the structural diversity of the trichomes and the leaf anatomy in this genus. Most descriptions have been published in the frame of general studies of the Boraginales, many of them decades or even more than a century age old (Kragge, 1911; Metcalfe and Chalk, 1950; Schibler, 1887; Solereder, 1908). Actual investigations of leaf anatomy within Boraginales S. Str. tribe Boraginaea are of Selvi and Bigazzi (2001). Within Heliotropiaceae, only few detailed studies were made by Bider (1935) of two species of Heliotropium, by Frohlich (1978) of leaf morphology and anatomy of 17 Mexican species of Heliotropium section Orthostachys, by Kumer and Rao (1994) of foliar epidermology of 6 species of Heliotropium, and by Difulvio (1982) of leaf anatomy of the monotypic Argentinian endemic Ixorhea. In addition, Heliotropium has some taxonomical problems in Flora Iranica and other references (Davis, 1965-1988; Nasir, 1970-2003; Riedl, 1978)

This research was aimed to study 12 species and also to add more data of leaf anatomy and especially anatomy characters for the family (a), thus to evaluate the systematic relevance and/or adaptive value of the morphological and anatomical diversity (b).

\section{Materials and methods}

Anatomic characteristics of twelve Iranian Heliotropium species were studied and then the anatomical characteristics were compared with each other (Tab. 2). Among them nine species were known as perennial and three species were known as annual species. The perennial species included Heliotropium bacciferum, $H$. ramossisimum, $H$. brevilimb, $H$. transoxanum, $H$. dasycarpum, $H$. dyginum, $H$. aucheri, $H$. carmanicum, and H.remotiflorum and the annual species are $H$. ellipticum, $H$. lasiocarpum, and $H$. suaveolens. Samples were removed from herbarium specimens at Tehran University Herbarium (TUH), IRAN (Tab. 1). Because samples did not dehydrated at the early stages of preparation, internal anatomy and epidermal structures including trichomes were maintained and instead of long time storage of excision, their slides were kept in laboratory. Because it was not needed to prepare durable slides, samples dehydration was not carried out and samples were stained directly after blanching by sodium hypochloride.

For preparing of the samples, leaves were fixed into alcohol-glycerin (1:1) for two months. Hand sections were made with a razor and from the middle portion of the leaf blade. The sections except for cellular contain were transferred to diluted hypochlorite sodium. Then samples were stained by methyl green and Bismarck brown. Appropriate samples were photographed by Olympus VANOX AHBS3 light microscope.

\section{Results}

Heliotropium bacciferum Forssk.

Midrib: T. S. midrib elliptic was $1.34 \times 1.47 \mathrm{~mm}$. Epidermis was regular sinuate. Palisade parenchyma located under upper and lower epidermis is presented, two short layers. Vascular bundles open arch. Distance of them from

Tab. 1. Heliotropium specimens used in the anatomical investigation

\begin{tabular}{|c|c|}
\hline Species & Voucher specimen \\
\hline H. bacciferum Forssk. & Hormozgan Province: Bandarabbas, Ostandary, Mobayen 4718-TUH. \\
\hline H. ramosissimum Bunge & $\begin{array}{l}\text { Hormozgan Province: Sirjan, } 200 \text { m, Ghahreman and Mozaffarian 5445-TUH. } \\
\text { Esfahan: Kashan-25km to Natanz, } 1150 \text { m, Ghahreman and Mozaffarian 1820-TUH. }\end{array}$ \\
\hline H. brevilimbe Boiss. & $\begin{array}{l}\text { Hormozgan Province Minab, Agriculture garden, Mobayen 22037-TUH; } \\
\text { Sistan and Bluchestan Province: Sarbaz, } 350 \mathrm{~m} \text {, Ghahreman and Mozaffaria , 14081-TUH; } \\
\text { Sistan and Bluchestan Province: Sarbaz, } 6 \text { km to Iranshahr, } 1000 \text { m, Mozaffarian 701333-TUH. }\end{array}$ \\
\hline H. remotiflorum Rech. & Sistan and Bluchestan Province: Hamoon, jazmorian, 300 m, Mozaffarian 45612-TUH. \\
\hline H. transoxanum Bge. & Khorassan Province: Birjand, 1500 m, Aliabadi 22275-TUH. \\
\hline H. dasycarpum Ledep. & $\begin{array}{l}\text { EsfahanProvince: } 10 \mathrm{~km} \text { East of Esfahan, } 900 \text { m, Akhani 5750-TUH; } \\
\text { Loot: Gavsephid, Mobayen s.n. }\end{array}$ \\
\hline H.digynum Forssk. & Khorassan Province: Bostan, 70 m, Mozaffarian 58517-TUH. \\
\hline H.aucheri DC. & $\begin{array}{l}\text { Tehran Province: Ghom, } 850 \text { m, Akhani, 5812-TUH; Esfahan Province: Natanz, } 1050 \\
\text { m, Akhani 5794-TUH; Gilan Province: Without collector 5660-TUH; } \\
\text { Esfahan Province: Kashan, } 1000 \text { m, Akhani 5799-TUH. }\end{array}$ \\
\hline H. carmanicum Bge. & $\begin{array}{l}\text { Khorassan Province: Between Shahrood and Sabzevar, } 860 \text { m, Ghahreman and Attar } \\
\text { 27333- TUH; Kerman Province: Between Bam and Mahrag, Mobayen s.n. }\end{array}$ \\
\hline H.ellipticum LEDEB. & $\begin{array}{l}\text { Tehran Province: Shahreziba, } 1250 \text { m, Akhani 5409-TUH; Gilan } \\
\text { Province: Roodbar, } 150 \text { m, Akhani and Lari 5652-TUH. }\end{array}$ \\
\hline H. lasiocarpum Fisch. & Sistan and Baluchestan Province: Zabol, $450 \mathrm{~m}$, Ghahreman and Akhani 5955-TUH. \\
\hline H. suaveolens M.B. & Azarbayejan Province: Arasbaran, $450 \mathrm{~m}$, Ghahraman and Mozaffarian 17596-TUH. \\
\hline
\end{tabular}


Tab. 2. Useful anatomical characters for distinguishing of species

\begin{tabular}{|c|c|c|c|c|c|c|c|c|c|c|c|c|c|}
\hline \multirow{2}{*}{ Species } & \multicolumn{6}{|c|}{ Midrib } & \multicolumn{7}{|c|}{ Lamina } \\
\hline & Shm & Sem & $\mathrm{Tpm}$ & Svm & Dvl & Dvu & $\mathrm{Al}$ & $\mathrm{Nlm}$ & Num & Lum & Tpm & $\mathrm{Tl}$ & $\mathrm{Tpl}$ \\
\hline H. bacciferum & $\mathrm{e}$ & er & $\mathrm{p}$ & 1 & $\mathrm{~h}$ & h' & $\mathrm{z}$ & $\mathrm{n}^{2}$ & $\mathrm{~m}^{\prime}$ & $\mathrm{c}$ & j & $\mathrm{t}^{\prime \prime}$ & si \\
\hline H. ramosissimum & o' & $\mathrm{y}$ & $\mathrm{P}$ & 1 & $\mathrm{f}$ & $f^{\prime}$ & $\mathrm{x}^{\prime \prime}$ & $n^{2}$ & $\mathrm{~m}^{\prime}$ & a & j & $\mathrm{t}$ & si \\
\hline H. brevilimbe & e & $\mathrm{i}$ & $\mathrm{P}$ & $\mathrm{k}$ & $\mathrm{h}$ & $g^{\prime}$ & $\mathrm{x}$ & $\mathrm{n}^{1}$ & $\mathrm{~m}$ & a & j & $\mathrm{t}$ & se \\
\hline H. transoxanum & o' & er & $\mathrm{p}$ & $\mathrm{k}$ & $\mathrm{g}$ & $\mathrm{f}^{\prime}$ & $x^{\prime \prime}$ & $\mathrm{n}^{2}$ & $\mathrm{~m}$ & $\mathrm{a}$ & $q$ & $t^{\prime}$ & se \\
\hline H.dasycarpum & o' & $\mathrm{i}$ & $\mathrm{P}$ & $\mathrm{k}$ & $\mathrm{g}$ & $g^{\prime}$ & $\mathrm{x}^{\prime}$ & $\mathrm{n}^{2}$ & $\mathrm{~m}$ & $\mathrm{~b}$ & $\mathrm{q}$ & $\mathrm{t}$ & se \\
\hline H. digynum & o' & $\mathrm{i}$ & $\mathrm{P}$ & $\mathrm{k}$ & $\mathrm{h}$ & g' & $x^{\prime \prime}$ & $n^{1-2}$ & $\mathrm{~m}$ & $\mathrm{a}$ & j & $\mathrm{t}$ & si \\
\hline H. aucheri & o & $\mathrm{i}$ & s & $\mathrm{k}$ & $\mathrm{g}$ & f' & $x^{\prime \prime}$ & $n^{2-3}$ & $\mathrm{~m}$ & a & $q$ & $t^{\prime}$ & se \\
\hline H. carmanicum & $\mathrm{t}$ & er & $\mathrm{p}$ & c & f & $f^{\prime}$ & $\mathrm{x}$ & $n^{2}$ & $\mathrm{~m}$ & $\mathrm{~b}$ & $q$ & $t^{\prime}$ & se \\
\hline H. ellipticum & o' & er & s & $\mathrm{k}$ & $\mathrm{g}$ & $f^{\prime}$ & $\mathrm{x}^{\prime}$ & $n^{1-2}$ & $\mathrm{~m}$ & $\mathrm{~b}$ & j & $\mathrm{t}$ & si \\
\hline H. lasiocarpum & o & $\mathrm{i}$ & s & c & $\mathrm{f}$ & $f^{\prime}$ & $x^{\prime \prime}$ & $\mathrm{n}^{1}$ & $\mathrm{~m}$ & c & j & $\mathrm{t}$ & se \\
\hline H. remotiflorum & o' & er & $s$ & $\mathrm{k}$ & $\mathrm{h}$ & h' & $\mathrm{x}$ & $n^{2}$ & $\mathrm{~m}$ & c & $q$ & $\mathrm{t}$ & $\mathrm{Se}$ \\
\hline H. suaveolens & e & $\mathrm{i}$ & s & $\mathrm{k}$ & $\mathrm{h}$ & $\mathrm{f}^{\prime}$ & $\mathrm{x}^{\prime \prime}$ & $\mathrm{n}^{2}$ & $\mathrm{~m}$ & $\mathrm{a}$ & j & $\mathrm{t}$ & $\mathrm{Si}$ \\
\hline
\end{tabular}

Midrib: Shm=shape of main midrib ( $\mathrm{e}=$ elliptic, $\mathrm{o}=$ orbicular, $\mathrm{o}^{\prime}=$ orbicular to semi elliptic, $\mathrm{t}=$ triangular); Sem=shape of vascular bundles of midrib $(\mathrm{e}=$ entire, $\mathrm{r}=$ regular sinuate, $\mathrm{i}=$ irregular sinuate, $\mathrm{er}=$ entire to regular sinuate); $\mathrm{Tpm}=\mathrm{type}$ of parenchyma cells under lower epidermis of midrib ( $s=$ spongeous parenchyma, $\mathrm{p}=$ Palisade parenchyma); $\mathrm{Svm}=$ shape of vascular bundles ( $\mathrm{l}=$ longitudinally, $\mathrm{k}=$ open arch, $\mathrm{c}=\mathrm{closed}$ arch); $\mathrm{Dvl}=$ distance of vascular bundles from lower epidermis ( $\mathrm{f}=0.0 .11$ to 0.20 $\mathrm{mm}, \mathrm{g}=0.21$ to $0.35 \mathrm{~mm}, \mathrm{~h}=0.36$ to $0.57 \mathrm{~mm}$ ); Dvu=distance of vascular bundles from upper epidermis $\left(\mathrm{f}^{\prime}=0.15\right.$ to $0.30, \mathrm{~g}^{\prime}=0.31$ to $0.42, \mathrm{~h}^{\prime}=0.43$ to 0.60$)$;

Lamina: Al, Angle of between two part of blade $\left(\mathrm{x}=10^{\circ}\right.$ to $45^{\circ}, \mathrm{x}^{\circ}=50^{\circ}$ to $65^{\circ}, \mathrm{x}^{\prime \prime}=70^{\circ}$ to $\left.120^{\circ}, \mathrm{z}=180^{\circ}\right)$; Nlm=Number of cellular of layers of lower mesophylla $\left(\mathrm{n}^{1}=\right.$ one layer $\mathrm{n}^{2}=$ tow layers, $\mathrm{n}^{1-2}=$ one to two layers, $\mathrm{n}^{2-3}=$ two to three layers); Num=number of cellular layers of upper mesophylla ( $\mathrm{m}=$ one layer, $\mathrm{m}^{\prime}=$ two to three layers); Lum=length of upper mesophylla ( $\mathrm{a}=0.13$ to $0.18 \mathrm{~mm}, \mathrm{~b}=0.19$ to $0.23 \mathrm{~mm}, \mathrm{c}=0.24$ to $0.41 \mathrm{~mm}$ ); $T p m=$ type of cell wall of upper mesophylla ( $\mathrm{j}=$ spongeous cells, $\mathrm{q}=$ pallisade cells); $\mathrm{T}=$ thickness of lamina ( $\mathrm{t}=0.24$ to $0.42 \mathrm{~mm}, \mathrm{t}^{\prime}=0.43$ to $0.57 \mathrm{~mm}, \mathrm{t}^{\prime \prime}=0.58$ to $0.83 \mathrm{~mm}$ ); $\mathrm{Tpl}=$ type of cell wall of lower mesophylla (si= sinuate, se= serrate)
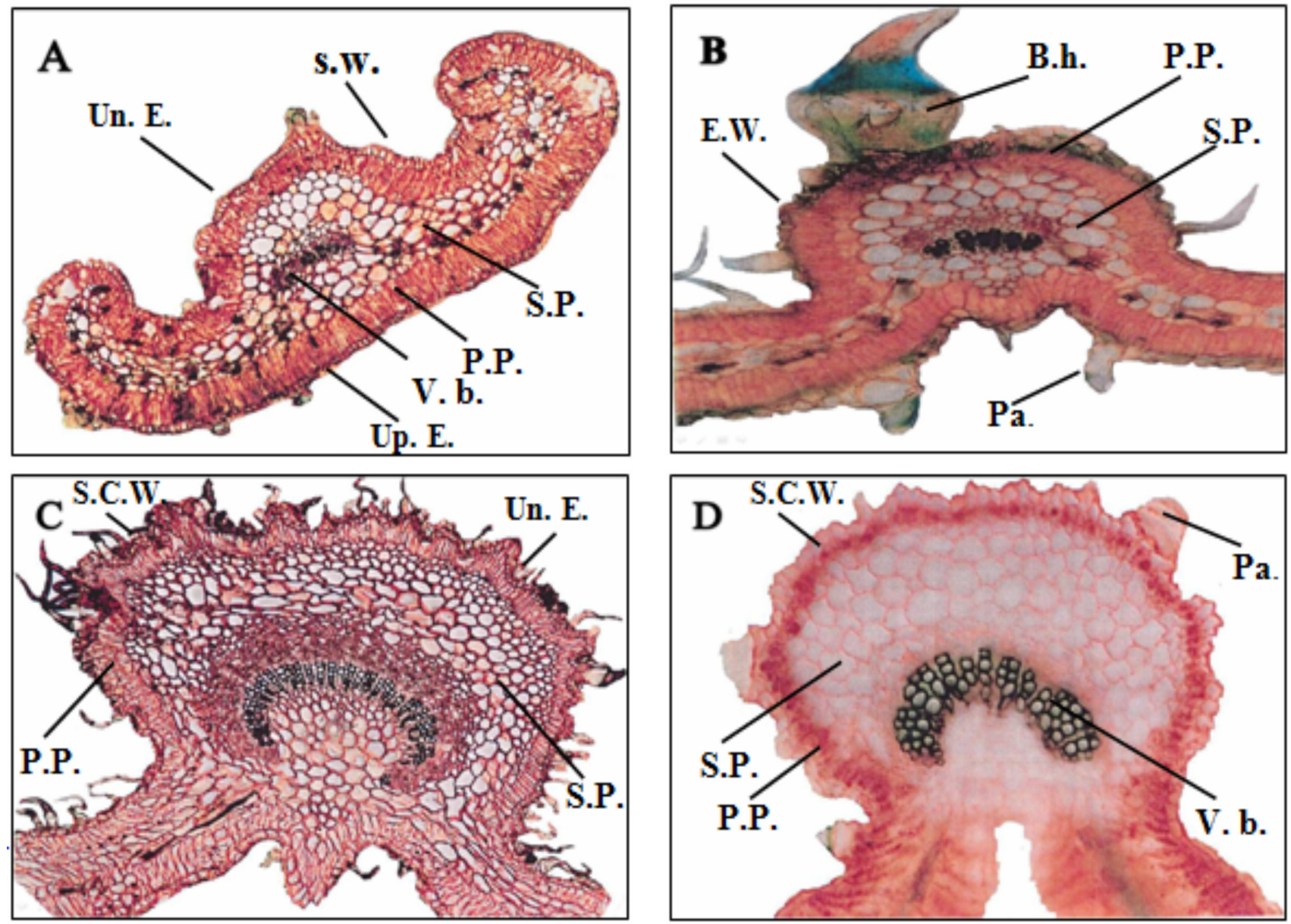

Fig. 1. Midrib of Heliotropium species in T.S; (A) H. bacciferum; (B) H. ramosissimum; (C) H. brevilimbe; (D) H. remotiflurum (Up.E.= Upper Epidermis; Un.E.=Under Epidermis; P.P.=Palisade Parenchyma; S.P.=spongeous Parenchyma; Cu.=Cuticle; B.h.=Bulbous hairs; Pa.=Papilla; S.C.W.=Sinuate Crisped wall; S.W.=Sinuate Wall; E.W.=Entire Wal; V.b.=Vascular bundles; Cr.=Crystal) 
38
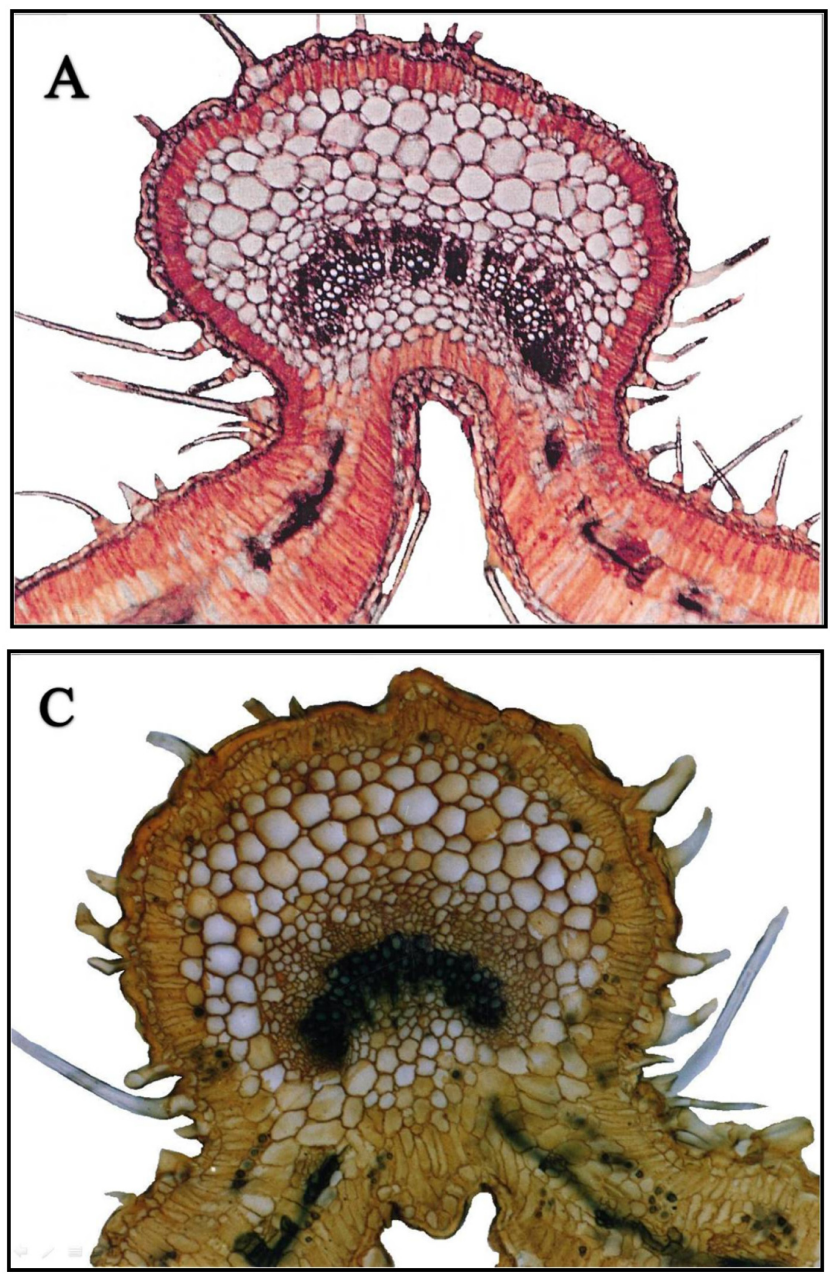

Fig. 2. Midrib of Heliotropium species in T.S; H. transoxanum (A)

lower and upper epidermis was measured 0.45 and 0.60 $\mathrm{mm}$, respectively (Fig. $1 \mathrm{~A})$.

Lamina: T.S. lamina was $0.83 \mathrm{~mm}$ in thickness. Angle of between two laminas was observed $180^{\circ}$. Palisade parenchyma of upper surface consists of 3 to 4 layers with $0.41 \mathrm{~mm}$ length. Palisade parenchyma of lower surface consists of 3 to 4 layers, short, with serrate wall and $0.50 \mathrm{~mm}$ length. Spongeous parenchyma in middle part of lamina had serrate wall. Crystal dispersed in two parts (Fig. 4 A).

\section{H. ramossisimum Bunge}

Midrib: T.S. midrib orbicular to semi elliptic was 0.55 $\times 0.65 \mathrm{~mm}$. epidermis was entire and covered by ticked cuticle. Palisade parenchyma under upper and lower surface is presented, two short layers. Vascular bundles were open arch to shallow and surrounded by phloem. Distance of them from lower and upper epidermis was 0.11 and 0.17 $\mathrm{mm}$, respectively. Bulbous hair in under epidermis is presented (Fig. 1 B).

Lamina: T.S. lamina was $0.40 \mathrm{~mm}$ in thickness. Angel of between two laminas was registered $120^{\circ}$. Epidermis was covered by ticked cuticle. Palisade parenchyma of lower epidermis consists of 2 layers with serrate wall. Palisade parenchyma under upper epidermis consists of 2
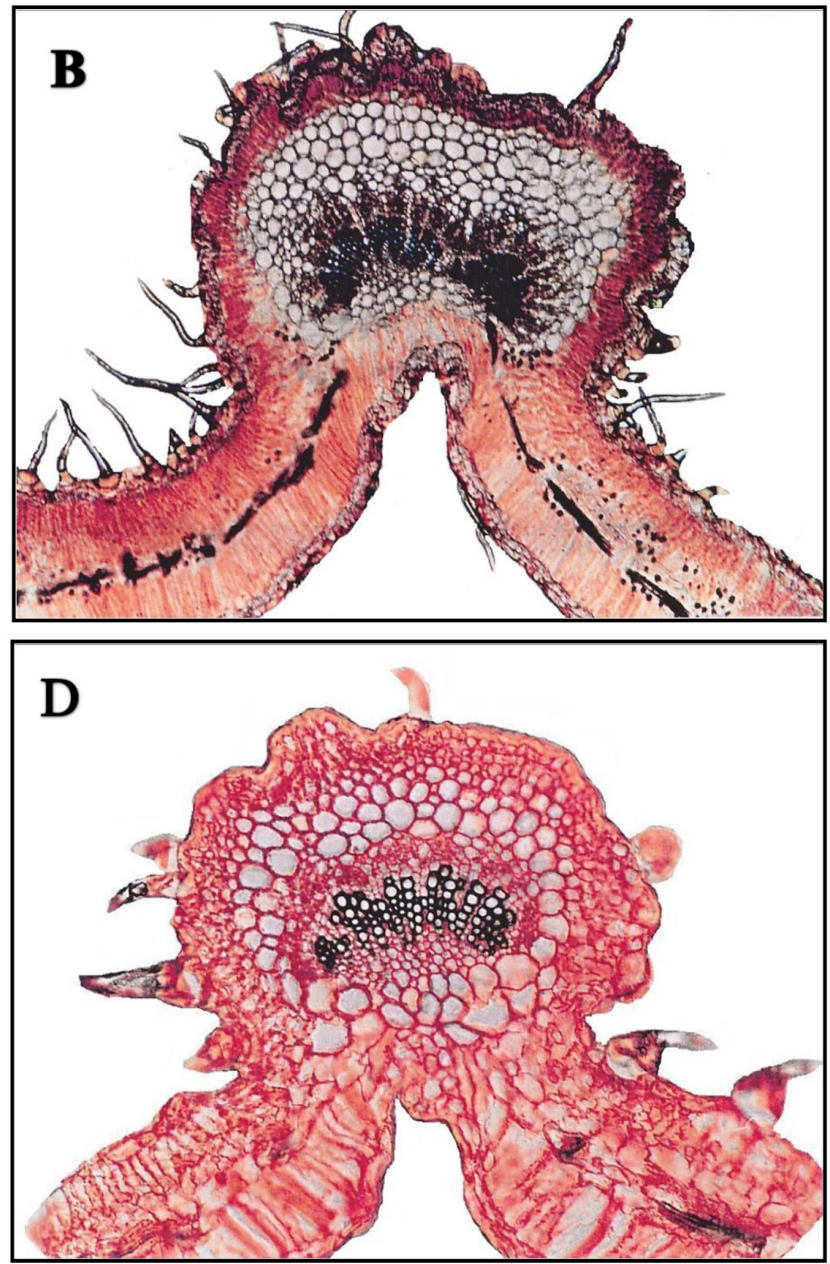

A); H. dasycaypum (B); H. digynum (C); H.ellipticum (D)

to 3 layers, with serrate wall and $0.13 \mathrm{~mm}$ length. Spongeous parenchyma in middle part of lamina consists of 2 to 3 layers, short and with sinuate wall. Density of bulbous hairs in upper epidermis was more than lower epidermis (Fig. 4 B).

\section{H. brevilimb Boiss.}

Midrib: T.S. midrib elliptic to orbicular was $1.40 \times$ $1.50 \mathrm{~mm}$. Epidermis was irregular sinuate crisped, covered by ticked cuticle. Palisade parenchyma under epidermis is presented, short and with sinuate wall. Vascular bundles were semi open and arch was surrounded by phloem and distance of them from lower and upper epidermis was 0.50 $\mathrm{mm}$ and $0.34 \mathrm{~mm}$, respectively. Bulbous hair and papilla is presented (Fig. 1 C).

Lamina: T.S. lamina was $0.30 \mathrm{~mm}$ in thickness. Angel of between two laminas was about $45^{\circ}$. Epidermis was covered by ticked cuticle. Palisade parenchyma of lower surface consists of single short layer with serrate wall. Palisade parenchyma under upper epidermis consists of one layer, with serrate wall, $0.18 \mathrm{~mm}$ length. Spongeous parenchyma in middle part of lamina consists of 2 to 3 layers. Density of bulbous serrate hairs in lower epidermis was more than upper epidermis (Fig. 4 C). 


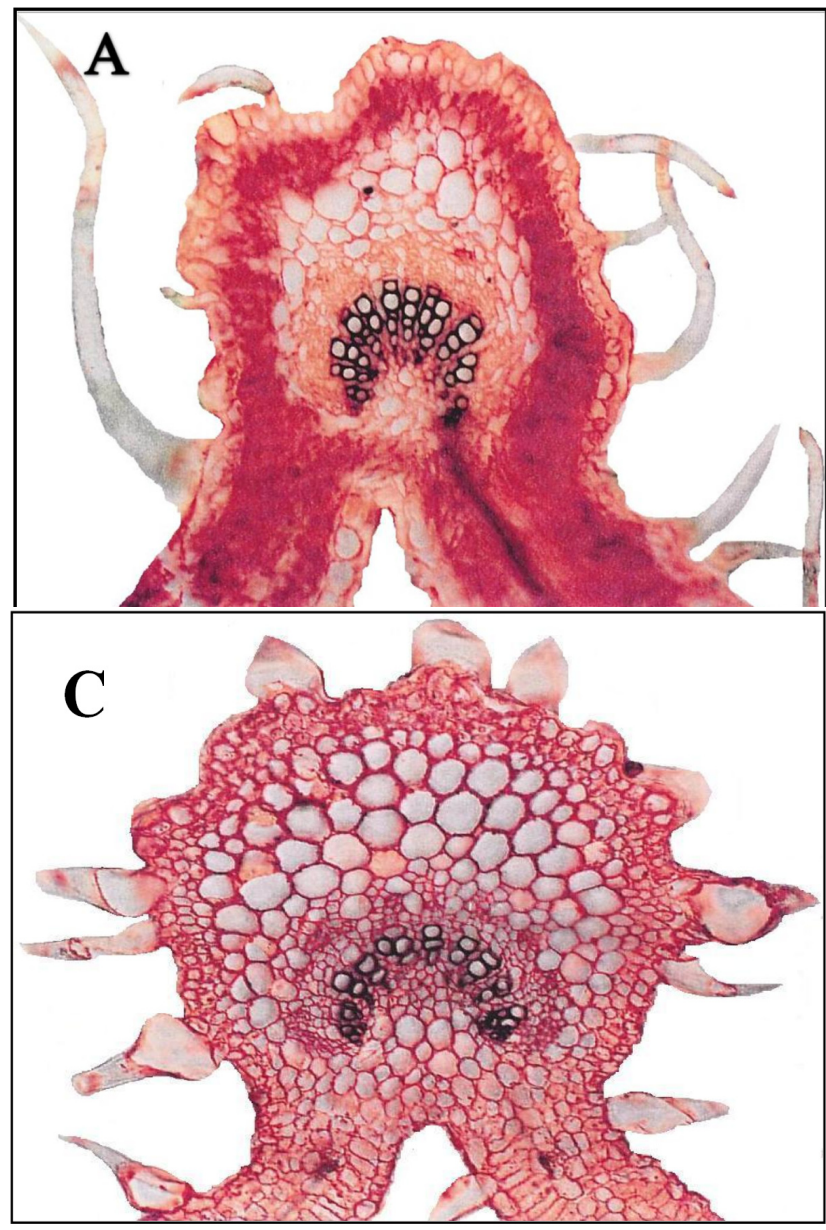

Fig. 3. Midrib of Heliotropium species in T.S; H. aucheri (A); H.

\section{H. transoxanum Rech.}

Midrib: T.S. midrib semi elliptic was $0.70 \times 0.85 \mathrm{~mm}$. Epidermis was entire to shallow irregular sinuate, covered by semi ticked cuticle. Palisade parenchyma under epidermis is presented one layer, short with sinuate wall and $0.88 \mathrm{~mm}$ length. Vascular bundles were open arch and surrounded by phloem and distance of them from lower and upper epidermis was $0.26 \mathrm{~mm}$ and $0.30 \mathrm{~mm}$, respectively (Fig. $2 \mathrm{~A}$ ).

Lamina: T.S. lamina was $0.57 \mathrm{~mm}$ in thickness. Angel of between two blades was $85^{\circ}$. Epidermis was covered by ticked cuticle. Palisade parenchyma of lower epidermis consists of 2 to 3 layers, short; with serrate to sinuate wall and $0.22 \mathrm{~mm}$ length. Palisade parenchyma under upper epidermis consists of single layer, with serrate wall, $0.23 \mathrm{~mm}$ length. Spongeous parenchyma in middle part of lamina consists of 2 to 3 layers, short and with sinuate wall. Density of bulbous hairs in upper epidermis was more than lower epidermis (Fig. $5 \mathrm{~A}$ ).

\section{H. dasycarpum Ledep.}

Midrib: T.S. midrib orbicular to elliptic was $0.75 \times$ $0.85 \mathrm{~mm}$. Epidermis with irregular sinuate wall and covered by ticked cuticle was observed. Palisade parenchyma of lower epidermis was $0.05 \mathrm{~mm}$ in diameter. Vascular bundles open arch surrounded with phloem and distance

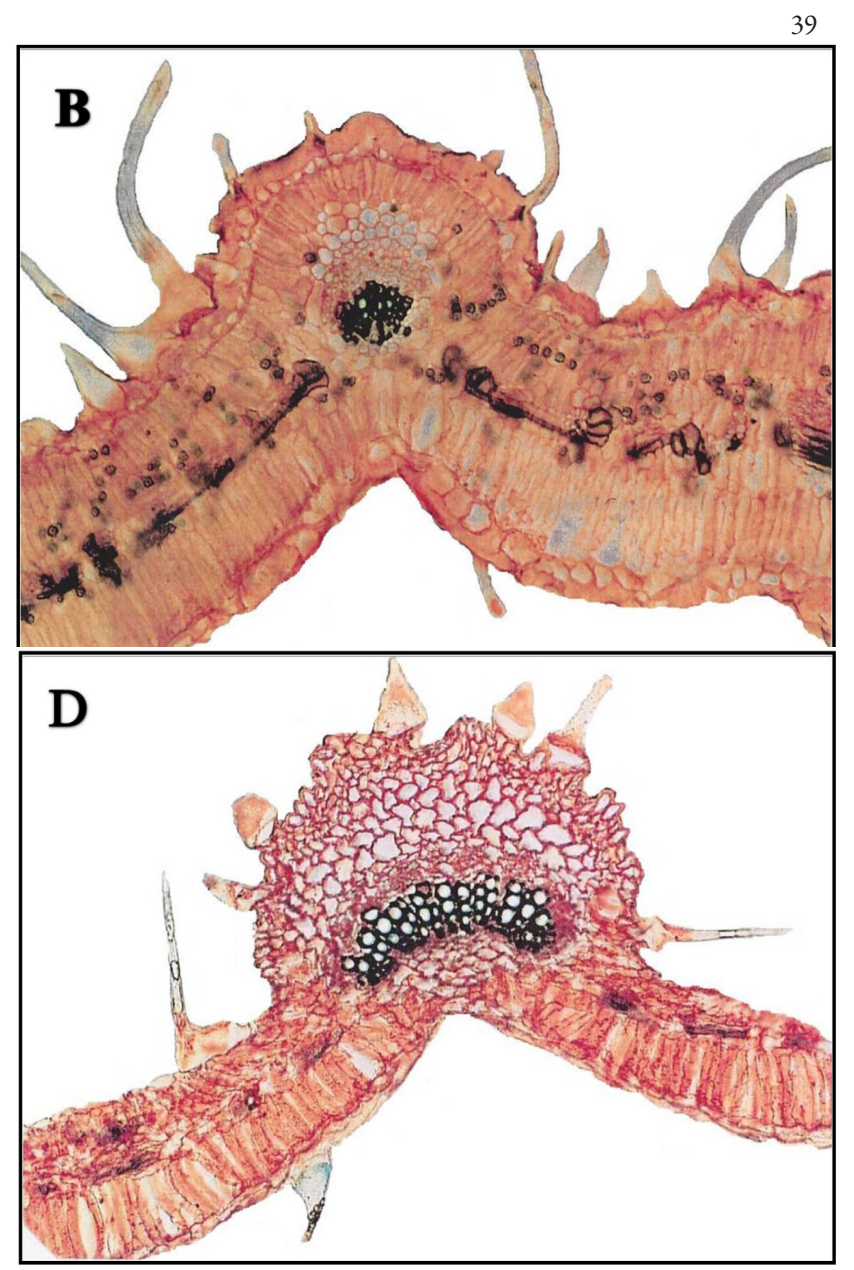

39

carmanicum (B); H. lasiocarpum (C); H. suaveolens (D)

of them from lower and upper epidermis $0.30 \mathrm{~mm}$ and $0.35 \mathrm{~mm}$, respectively (Fig. $2 \mathrm{~B}$ ).

Lamina: T.S. lamina was $0.42 \mathrm{~mm}$ in thickness. Angel of between two blades was $50^{\circ}$. Epidermis was covered by ticked cuticle. Palisade parenchyma of lower epidermis consists of two layers, short, with $0.21 \mathrm{~mm}$ length serrate wall. Palisade parenchyma under upper epidermis consists of one layer, $0.16 \mathrm{~mm}$ long. Density of bulbous hairs in lower epidermis was more than upper (Fig. 5 B).

\section{H. dyginum Forssk.}

Midrib: T.S. midrib orbicular to elliptic was $0.75 \times$ $0.78 \mathrm{~mm}$. Epidermis with irregular sinuate crisped wall, covered by ticked cuticle. Palisade parenchyma under 1 epidermis is presented two $0.5 \mathrm{~mm}$ length layers, Vascular bundles open to close arch, surrounded by phloem and distance of them from lower and upper epidermis was $0.45 \mathrm{~mm}$ and $0.42 \mathrm{~mm}$, respectively (Fig. $2 \mathrm{C}$ ).

Lamina: T.S. lamina was $0.32 \mathrm{~mm}$ in thickness. Angel of between two blades was $110^{\circ}$ and epidermis was covered by ticked cuticle. Palisade parenchyma in lower surface consists of two layers, short and serrate to sinuate with $0.16 \mathrm{~mm}$ long wall. Palisade parenchyma under upper epidermis consists of two layers, with serrate wall, $0.17 \mathrm{~mm}$ long. Serrate bulbous hairs in two surfaces were presented (Fig. 5 C). 
40
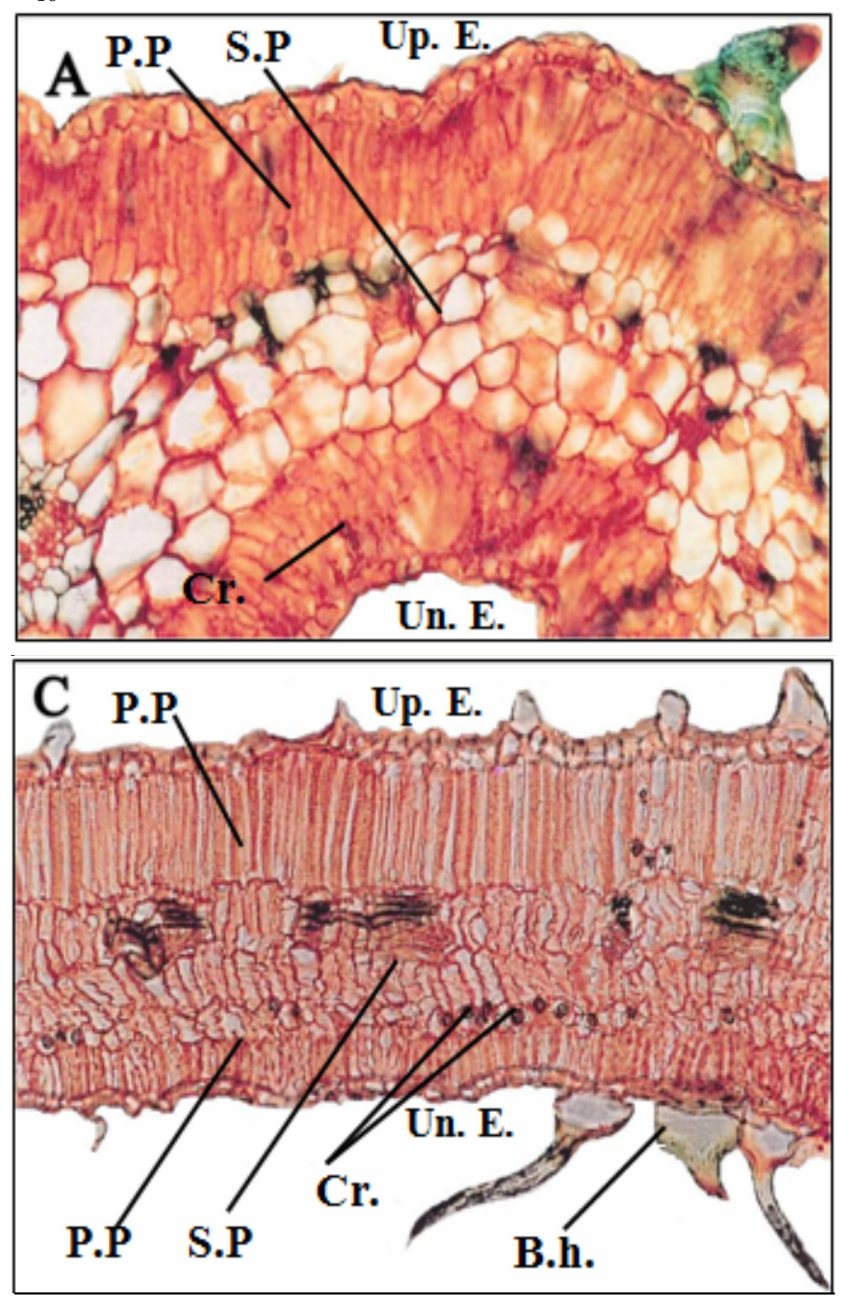
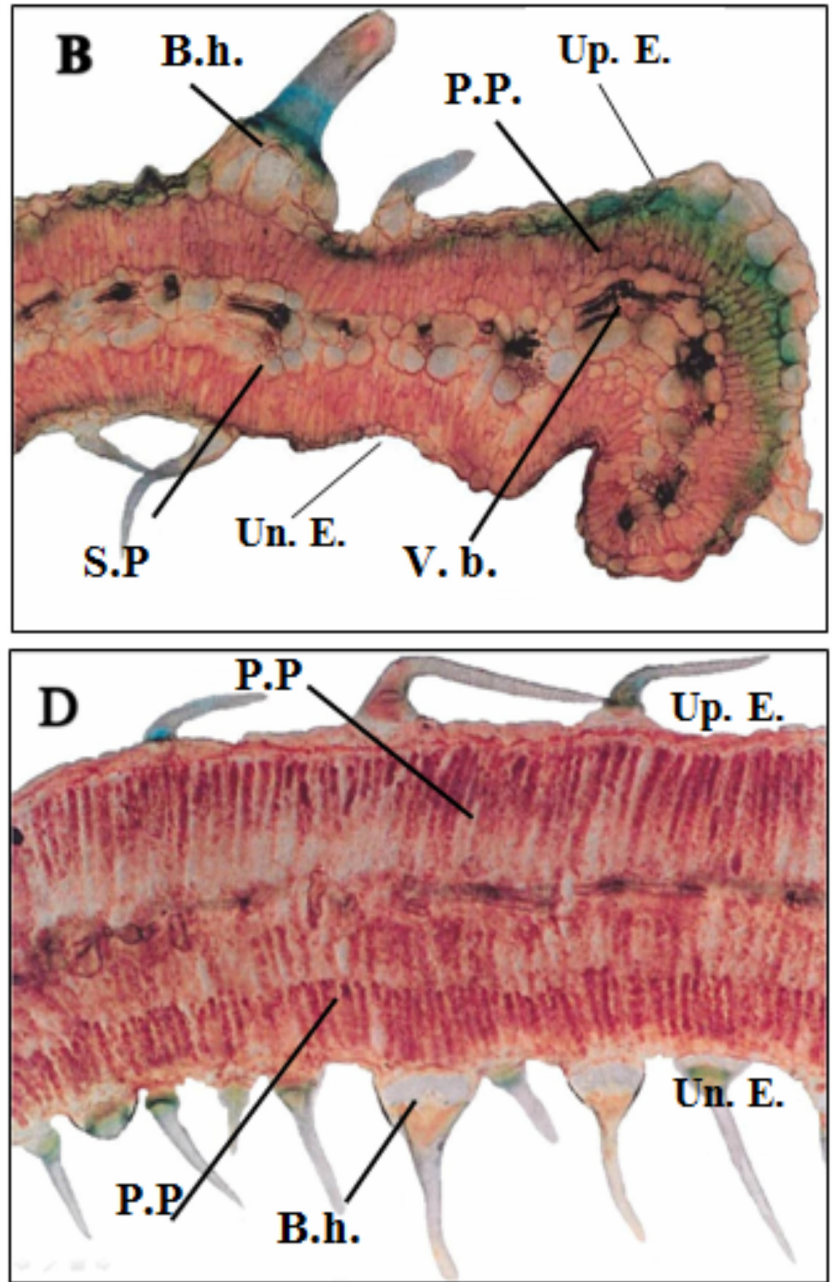

Fig. 4. Lamina of Heliotropium species in T.S; (A) H. bacciferum; (B) H. ramosissimum; (C) H. brevilimbe; (D) H. remotiflurum. Up.E. = Upper Epidermis; Un.E.=Under Epidermis; P.P.=Palisade Parenchyma; S.P.=spongeous Parenchyma; Cu.=Cuticle; B.h.=Bulbous hairs; Pa.=Papilla; Si.W.=Sinuate wall; Se.W.=Serrate wall; V. b.=Vascular bundles; Cr.=Crystal)

\section{H. aucheri DC.}

Midrib: T.S. midrib orbicular was $0.70 \times 0.75 \mathrm{~mm}$. Epidermis was entire to irregular sinuate crisped, covered by ticked cuticle. Spongeous parenchyma under epidermis is presented. Vascular bundles open arch surrounded by phloem and distance of them from lower and upper epidermis 0.21 and $0.30 \mathrm{~mm}$, respectively (Fig. $3 \mathrm{~A}$ ).

Lamina: T.S. lamina was $0.57 \mathrm{~mm}$ in thickness. Angel of between two blades was $85^{\circ}$. Epidermis was covered by ticked cuticle. Palisade parenchyma of lower epidermis consists of 2 to 3 layers, short and serrate to sinuate with $0.22 \mathrm{~mm}$ length wall. Palisade parenchyma under upper epidermis consists of single layer, with serrate $0.23 \mathrm{~mm}$ length wall. Spongeous parenchyma in middle part of lamina consists of 2 to 3 short layers with sinuate wall. Density of bulbous hairs in upper epidermis was more than lower epidermis (Fig. $6 \mathrm{~A}$ ).

\section{H. carmanicum BGE.}

Midrib: T.S. midrib orbicular to elliptic was $0.42 \times$ $0.55 \mathrm{~mm}$. Epidermis with entire to shallow sinuate crisped wall, covered by ticked cuticle. Palisade parenchyma under epidermis is presented one layer with $0.8 \mathrm{~mm}$ long. Vascular bundles close arch surrounded by phloem and distance of them from lower and upper epidermis was 0.20 and $0.23 \mathrm{~mm}$ (Fig. $3 \mathrm{~B}$ ).

Lamina: T.S. lamina was $0.53 \mathrm{~mm}$ in thickness. Angel of between two blades was $30^{\circ}$. Epidermis covered by ticked cuticle. Palisade parenchyma of lower epidermis consists of 2 to 3 short layers with serrate to sinuate 0.19 $\mathrm{mm}$ length wall. Palisade parenchyma located under upper epidermis consists of one layer, long, $0.23 \mathrm{~mm}$ in diameter. Spongeous density of bulbous hairs in lower epidermis was more than upper epidermis (Fig. 6 B).

\section{H. ellipticum Ledeb.}

Midrib: T.S midrib orbicular to elliptic was $0.55 \times$ $0.65 \mathrm{~mm}$. covered by ticked cuticle. Epidermis was entire to shallow sinuate crisped. Spongeous parenchyma under epidermis is presented. Vascular bundles open arch, surrounded by phloem and distance of them from lower and upper epidermis was 0.22 and $0.30 \mathrm{~mm}$, respectively (Fig. $2 \mathrm{D})$. 

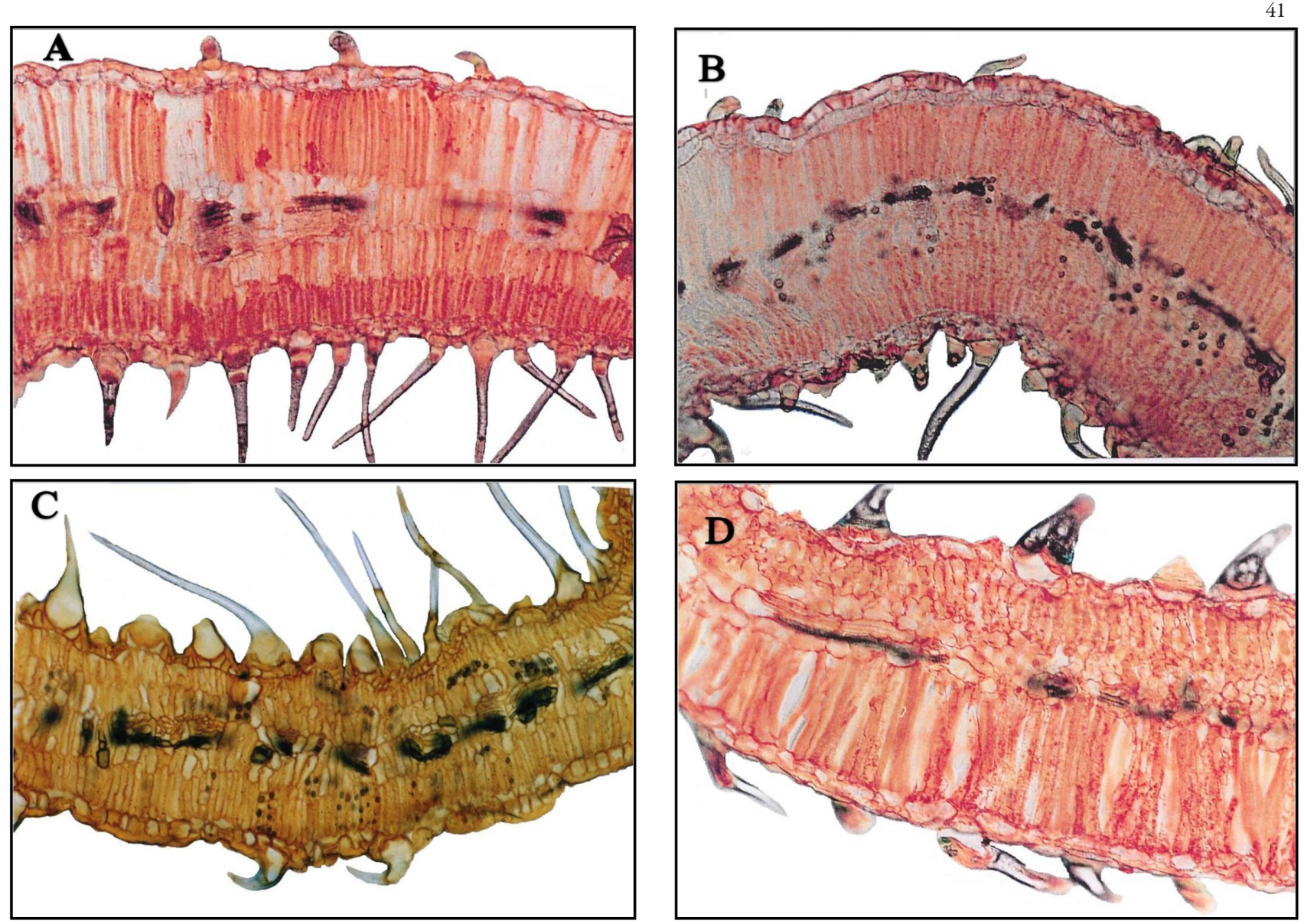

Fig. 5. Lamina of Heliotropium species in T.S; H. transoxanum (A); H. dasycaypum (B); H. digynum (C); H. ellipticum (D)

Lamina: T.S. lamina was $0.42 \mathrm{~mm}$ in thickness. Angel of between two laminas was $65^{\circ}$. Palisade parenchyma under lower epidermis consist one short layer with serrate wall. Palisade parenchyma of upper surface consists of single long layer with serrate $0.24 \mathrm{~mm}$ length wall. Spongeous parenchyma in middle part of lamina is presented two layers, with sinuate to serrate wall. In some area, it changes to short palisade parenchyma. Density of the hairs in lower epidermis was more than upper epidermis (Fig. 5 D).

\section{H. lasiocarpum Fisch.}

Midrib: T.S midrib orbicular was $58 \times 56 \mathrm{~mm}$. Epidermis with regular sinuate crisped wall, covered by ticked cuticle. Collenchyma under epidermis is presented, 0.25 $\mathrm{mm}$ in diameter. Vascular bundles open to close arch, surrounded by phloem and distance of them from lower and upper epidermis was 0.17 and $0.15 \mathrm{~mm}$, respectively. Bulbous hairs is presented (Fig. $3 \mathrm{C}$ ).

Lamina: T.S. lamina was $0.26 \mathrm{~mm}$ in thickness. Angel between two laminas was $70^{\circ}$. Epidermis covered by thin cuticle. Palisade parenchyma under lower epidermis is presented one short layer with serrate wall. Palisade parenchyma of upper surface consists of single layer, with serrate $0.21 \mathrm{~mm}$ length wall. Spongeous parenchyma in middle part of lamina is presented two layers, with sinuate to serrate wall. In some area, it changes to short palisade parenchyma. Density of hairs in both surfaces was equal (Fig. 6C).

\section{H. remotiflorum Rech.}

Midrib: T.S. midrib orbicular to elliptic was $0.57 \times$ $0.62 \mathrm{~mm}$. Epidermis with entire to regular sinuate crisped wall, covered by cuticle. Collenchymas under epidermis are presented. Vascular bundles open arch, surrounded by phloem and distance of them from lower and upper epidermis was 0.50 and $0.34 \mathrm{~mm}$, respectively (Fig. $1 \mathrm{D}$ ).

Lamina: T.S. lamina was $0.32 \mathrm{~mm}$ in thickness. Angel of between two laminas was $10^{\circ}$. Palisade parenchyma under lower epidermis consists two $0.14 \mathrm{~mm}$ long layers with serrate wall. Palisade parenchyma of upper surface was single long layer, with serrate $0.16 \mathrm{~mm}$ length wall. Density of bulbous serrate hairs in lower epidermis was more than upper epidermis (Fig. 4 D).

\section{H. suaveolense M.B.}

Midrib: T.S. midrib elliptic was $0.53 \times 0.70 \mathrm{~mm}$. Epidermis with irregular sinuate crisped wall, covered by thin cuticle. Collenchyma under epidermis is presented. Vascular bundles open arch, surrounded by phloem and distance of them from lower and upper epidermis 0.32 and 0.19 $\mathrm{mm}$, respectively (Fig. $3 \mathrm{D}$ ). 

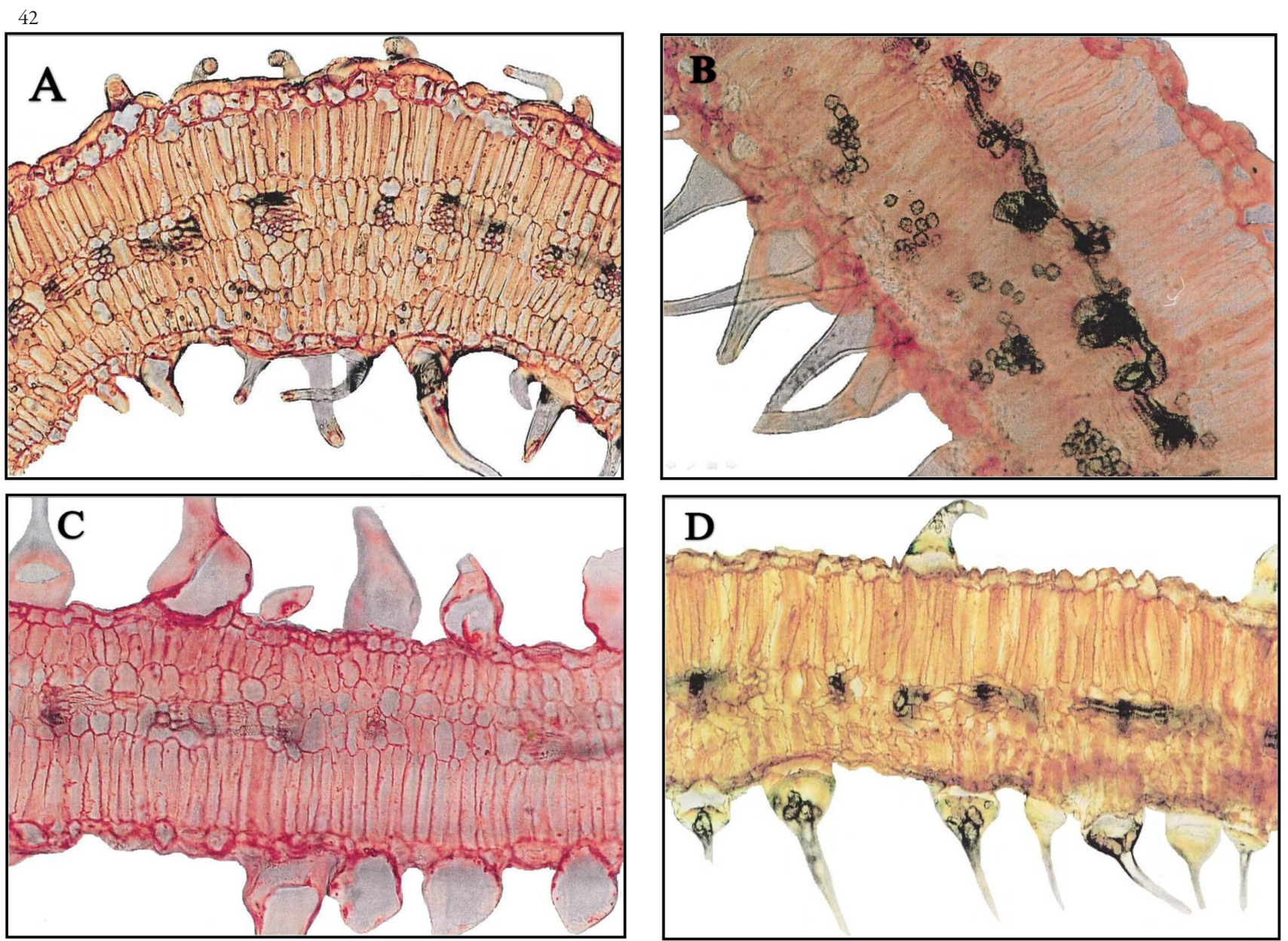

Fig. 6. Lamina of Heliotropium species in T.S; H. aucheri (A); H. carmanicum (B); H. lasiocarpum (C); H. suaveolens (D)
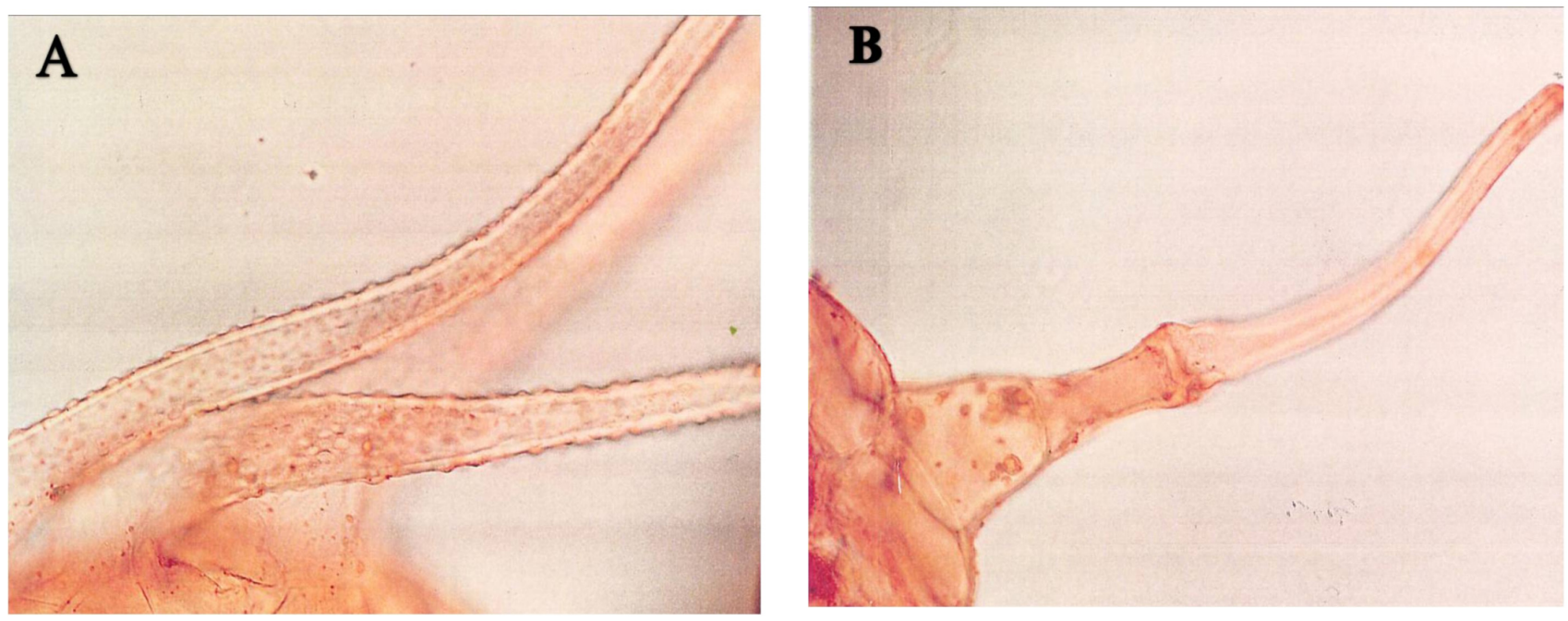

Fig. 7. Serrate bulbous hair in Heliotropium sp (A); Three cellular bulbous hair Heliotropium sp (B)

Lamina: T.S. lamina was $0.24 \mathrm{~mm}$ in thickness. Angel of between two blades was $100^{\circ}$. Palisade parenchymas under lower epidermis consist of two short layers with sinuate to serrate $0.10 \mathrm{~mm}$ long wall. Palisade parenchyma of upper surface was single layer, with serrate wall, and 0.18 mm length (Fig. $6 \mathrm{D}$ ).

\section{Disccusion}

Although $H$. bacciferum and $H$. ramosissimum are similar to each other in terms of morphology, they are different in anatomic characteristics. On the other hand in $H$. bacciferum angle between two blades was $180^{\circ}$; and cross section of main midrib was elliptic while the angle in $H$. 
ramosissimum was $120^{\circ}$ and shape of the midrib was orbicular. In respect of anatomy, cross section of main midrib in $H$. brevilimbe and $H$. remotiflorum was orbicular and vascular bundles are open arch, but lamina in two species was different; lower mesophylla in $H$. brevilembe consists of one short layer palisade parenchyma, while under lower parenchyma in $H$. remotiflorum consists of only two layers of long palisade parenchyma without spongeous cells.

In previous investigation (Akhani, 1991) H. carmanicum was described as H. aucheri subsp. Carmanicum. Anatomical characteristics were used to clarify the boundaries between $H$. aucheri and $H$. carmanicum which are independent species in Flora Iranica.

$H$. aucheri and $H$. carmanicum are independent species anatomically, because cross section of main midrib in $H$. aucheri was orbicular and consist of collenchymas under epidermis and had open arch vascular bundles whereas in $H$. carmanicum cross section of main midrib was almost triangular and one layer of palisade parenchyma exists under lower epidermis of midrib and vascular bundles was closed to arch, also epidermis of main midrib had irregular sinuate crisped in this species.

$H$. transoxanum and $H$. dasycarpum showed some differences in terms of anatomic characteristics; in $H$. transoxanum under epidermis of main midrib is entire to regular crisped with low depth and there was not any crystals in lamina, whereas in $H$. dasycarpum lower epidermis had irregular crisped and many crystals dispersed in lower mesophylla. Balbuse hairs with serrate walls were observed in whole investigated species.

The aim was to evaluate the systematic relevance of their diversity as compared to recent findings of systematic relationships within the genus. We conclude that two species $H$. aucheri and $H$. carmanicum are independent species but we can accept $H$. transoxanum as a sub group of $H$. dasycarpum.

\section{References}

Akhani H (1991). Revision of sub family Heliotropioideae (Boraginaceae) in Iran. M.Sc Thesis of Biology, College of Plant Science, Tehran University, Tehran, Iran.

Akhani H (2007). Diversity, biogeography and photosynthetic pathways of Argusia and Heliotropium (Boraginaceae) in South-West Asia with an analysis of phytogeographical units. Bot J Linn Soci 155:401-425.
Akhani H, Förther H (1994). The genus Heliotropium L. (Boraginaceae) in Flora Iranica area. Sendtnera 2:187-276.

Bigazzi M (2001). Leaf surface and anatomy in Boraginaceae tribe Boragineae with respect to ecology and taxonomy. Flora 196:269-285.

Craven LA (1996). A taxonomic revision of Heliotropium (Boraginaceae) in Australia. Austr System Bot 9:521-657.

Davis PH (Ed) (1965-1988). Flora of Turkey and the East Aegean Islands, Vols. 1-10. Edinburgh: Edinburgh University Press.

Diane N, Förther H, Hilger H (2002). Asystematic analysis of Heliotropium, Tournefortia, and allied taxa of the Heliotropiaceae (Boraginales) based on ITS1 sequences and morphological data. Am J Bot 89:287-295.

Difulvio TE (1982). Sobre la anatomia foliar y estomatogenesis de Ixorhea tschudiana (Heliotropiaceae). Kurtziana 15:9-18

Frohlich MW (1978). Systematics of Heliotropium sect. Orthostachys in Mexico. PhD Thesis in Biology. Harvard University.

Johnston IM (1928). Studies in the Boraginaceae VII: the South American species of Heliotropium. Contrib Gray Herb 81:1 83.

Kellogg EA (1999). Phylogenetic aspects of the evolution of $\mathrm{C}_{4}$ photosynthesis, p. 411-444. In: Sage F, Monson RK (Eds.). C4 Plant Biology. San Diego, CA, Academic Press.

Kumar KV, Rao BH (1994). A contribution to the foliar epidermology of Heliotropium. J Swamy Bot Cl 11:12-19.

Metcalf CR, Chalk L (1985). Anatomy of the cotyledons. Oxford Univ. Press.

Nasir E, Ali SI, Qaisar M (Eds.) (1970-2003). Flora of Pakistan, Vols. 1-210. Karachi, University of Karachi.

Nasir Y (1989). Heliotropium, p. 18-50. In: Nasir E, Ali SI (Eds.). Flora of Pakistan, Vol. 191. Karachi, University of Karachi.

Riedl H (1978). Boraginaceae, In: Rechinger KH (Ed.). Flora Iranica, Lfg., Graz:

Ziegler H, Batanouny KH, Sankhla N, Vyas OP, Stichler W (1981). The photosynthetic pathway types of some desert plants from India, Saudi Arabia, Egypt, and Iraq. Oecologia 48:93-99. 